
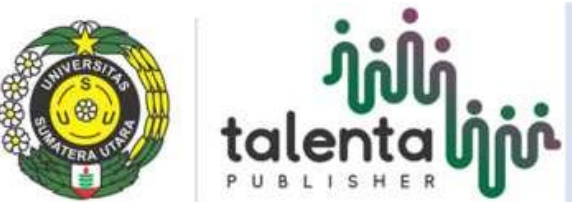

\title{
Evaluation of Beef Meat Quality at Slaughterhouse in Kendari City
}

\author{
H. Hafid*, M. Dzikrullah, R. Aka, and Nuraini \\ Animal Science Program Study, University of Halu Oleo Andunohu, Kendari, Indonesia. \\ *Correspondent author: harapin.hafid@uho.ac.id
}

\begin{abstract}
This study aims to find out whether DFD (Dark, Firm, and Dry) and PSE (Pale, Soft, and Exsudative) happen/ occur to Bali Cattle Carcas slayed in Anggoeya Animal Slaugtherhouse in Kendari City. This study is useful to give information about the meats' DFD and PSE cases and carcas quality at Anggoeya Slaugtherhouse in Kendari City. The sample of this study are 6 bulls and 6 cows taken from slaugtherhouse in Kendari City. The obtained data was, then, analyzed descriptively based on the mean and deviation standard $(\chi \pm \mathrm{SD})$. The variables observed in this studyincludes PH measurement for $1-6$ hours after slashing, color, loss of mass, texture, hardness, and humidity. The meats were found to be around normal PH 5.55 - 5.73. Based on the color score AUS_MEAT Colour, the color of the meats was around the score of $4-5$, loss of mass was around $30,64-43,28 \%$. Based on panelis judgement, most of the meats texture were scored 3 or were in moderate level. Most of the meats' elasticity were scored 3 or were rather soft, while most of the meats' humidity were scored 3 or moderate $(62.50 \%)$. On the meats produced by the Animals Slaugtherhouse in Kendari City, no changes to DFD (Dark, Firm, and Dry) or PSE (Pale, Soft and Exudative) was found.
\end{abstract}

Keywords: DFD, PSE, Carcasses, Bali Cattle

Received [9 April 2020] | Revised [15 April 2020] |Accepted [21 April 2020]

\section{Introductions}

Meat Safe, Healthy, Whole and Halal (ASUH) is a need that is highly emphasized byconsumers. Until now, the existence of these facilities and infrastructure, especially meat sales kiosks, have largely not met the minimum sanitation hygiene requirements so that they have not met ASUH criteria (Directorate for Kesmavet, 2005).

ASUH beef can be obtained if the process of handling from the process of transportation tothe feeding process undergo a good meat processing procedure. The process of handling livestock from the time of transportation to the process of slaughtering has a relationship with good or bad meatproduced (Hafid et al. 2010).

Carcasses obtained from good slaughtering animals will certainly produce meat that is safefor consumption because it has gone through good slaughtering standards in slaughterhouses becauseit has been examined for possible disease (Hafid, 2008; 2011). Healthy meat will also not be obtained from slaughterhouses that meet the standards because sick animals that have the 
potential to produce unhealthy meat will not be slaughtered. Halal meat is meat obtained from slaughter according to Islamic law. Based on preliminary observations made at the slaughterhouse of the City of Kendari, some of the newly arrived cattle were immediately slaughtered and had not yet been rested, fasted, and health checks were carried out on the animals.

In connection with the description, it is necessary to carry out research on the physical and organoleptic quality of the bali beef carcass produced at the slaughterhouse in Kendari City especiallyon the possibility of the occurrence of dark, dry and rough meat or often also known as dark, firm and dry (DFD) also to the possibility of the occurrence of pale, soft and runny meat or called Pale, Softand Exsudative (PSE) which is of very low quality and can also be investigated on the quality of carcasses cut at Kendari Slaughterhouse of Kendari City.

\section{Materials and Methods}

The research material used in this study was the longissimus dorsi muscle of male and female bali cattle each with 6 heads that have a uniform age (2-3 years). The tools used in this research are in the form of digital $\mathrm{pH}$ meters, digital scales, furnaces, glass cups, cutters, cutters, aquadest, and blenders.

The study was conducted by direct observation of a number of cows made into samples to be tested in the laboratory. Primary data is data obtained by direct observation of meat shortly after beingcut, meat texture, meat color, hardness of meat, and moisture of meat owned by the meat under study.

\section{Results and Discussion}

Meat has a meat structure consisting of muscle tissue, connective tissue, blood vessels and nerve tissue. According to SNI (1995) tendon attached to the skeleton, except tendon from the lips, nose and ears that come from healthy cows / buffaloes when slaughtered.

DFD (Dark Firm Dry) meat, which is dark, hard-textured, dry meat, has a high pH value and highwater binding capacity (Arief et al., 2000; Hafid, 2010; 2011). Conversely, due to stress factors and other factors not yet known, the decrease in $\mathrm{pH}$ can take place very quickly and is very low. 


\subsection{Meat pH}

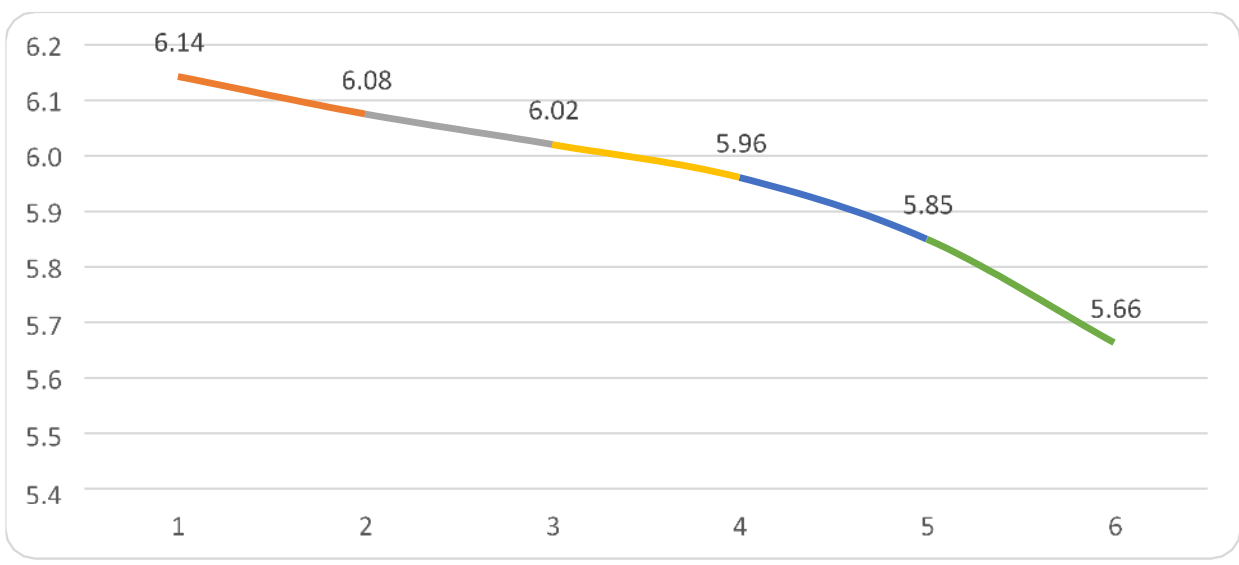

Figure 1. Observation Results of $\mathrm{pH}$

The $\mathrm{pH}$ of Bali beef after being observed for 6 hours after slaughtering is still in normal condition, ranging from 5.55 to 5.73 as in Appendix 1. The decrease in $\mathrm{pH}$ that occurs in male and female cattle is still in normal level because it is still in the threshold Normal meat $\mathrm{pH}$ ie normal muscle tissue pH from 6.5 to 6.6 will drop to 5.3-5.5 (Koswara, 2009). Based on the results of research conducted by Prasetyo et al. (2013) in three Malang City Markets namely Dinoyo Market, Blimbing Market and Besar Market, the average $\mathrm{pH}$ of the three markets in Malang has an average of

5.63. Results of research conducted by Prasetyo et al. (2013) when compared with research conductedat the Kendari City Slaughterhouse did not have much difference because the average obtained in this study was a $\mathrm{pH}$ value of 5.95 .

\subsection{Comparison of Meat Color}

Table 1. Color Observation Results

\begin{tabular}{lcccccccccc}
\hline \multirow{2}{*}{ Sample } & \multicolumn{10}{c}{ Colour Score } \\
\cline { 2 - 11 } & $\mathbf{0}$ & $\mathbf{1 b}$ & $\mathbf{1 c}$ & $\mathbf{2}$ & $\mathbf{3}$ & $\mathbf{4}$ & $\mathbf{5}$ & $\mathbf{6}$ & $\mathbf{7}$ \\
\hline Female 1 & 0 & 0 & 0 & 0 & 0 & 0 & 1 & 0 & 0 \\
Female 2 & 0 & 0 & 0 & 0 & 0 & 1 & 0 & 0 & 0 \\
Female 3 & 0 & 0 & 0 & 0 & 0 & 0 & 1 & 0 & 0 \\
Female 4 & 0 & 0 & 0 & 0 & 0 & 0 & 1 & 0 & 0 \\
Female 5 & 0 & 0 & 0 & 0 & 0 & 0 & 1 & 0 & 0 \\
Female 6 & 0 & 0 & 0 & 0 & 0 & 0 & 1 & 0 & 0 \\
Male 1 & 0 & 0 & 0 & 0 & 0 & 0 & 1 & 0 & 0 \\
Male 2 & 0 & 0 & 0 & 0 & 0 & 1 & 0 & 0 & 0 \\
Male 3 & 0 & 0 & 0 & 0 & 0 & 1 & 0 & 0 & 0 \\
Male 4 & 0 & 0 & 0 & 0 & 0 & 0 & 1 & 0 & 0 \\
Male 5 & 0 & 0 & 0 & 0 & 0 & 0 & 1 & 0 & 0 \\
Male 6 & 0 & 0 & 0 & 0 & 0 & 1 & 0 & 0 & 0 \\
\hline Frequency & 0 & 0 & 0 & 0 & 0 & 4 & 8 & 0 & 0 \\
\hline Percentage (\%) & 0 & 0 & 0 & 0 & 0 & 33,33 & 66,67 & 0 & 0 \\
\hline
\end{tabular}

Measuring the color of beef using a standard color of beef with a score of 1-9, ranging from pink to dark red, that is bright red (score 0-3), dark red / slightly darker (score 4-5) and color dark red 
(score 6-7) (Meat and Livestock Australia, 2012). Comparison of meat color in Bali beef after measuring for 6 hours after slaughtering resulted in the frequency occurrence of score 4 in bright red as much as $33.33 \%$ while the frequency of occurrence of score 5 in red as much as $66.67 \%$. This shows the color of bali beef slaughtered at the Kendari City Slaughterhouse is the normal color ofbeef and not identified by DFD and PSE. Based on the results of research by Kuntoro et al. (2013) LDmeat has a score of 6 (bright red), while BF meat has a score of 7 (red is a bit darker). From the resultsof research by Kuntoro et al. (2013), the color of meat produced with different scales but has the samecolor because the color standard used by Kuntoro et al. (2013) is the meat color standard SNI 3932: 2008 while the scale used in this study is AUS-MEAT color scale.

\subsection{Shrink Cook}

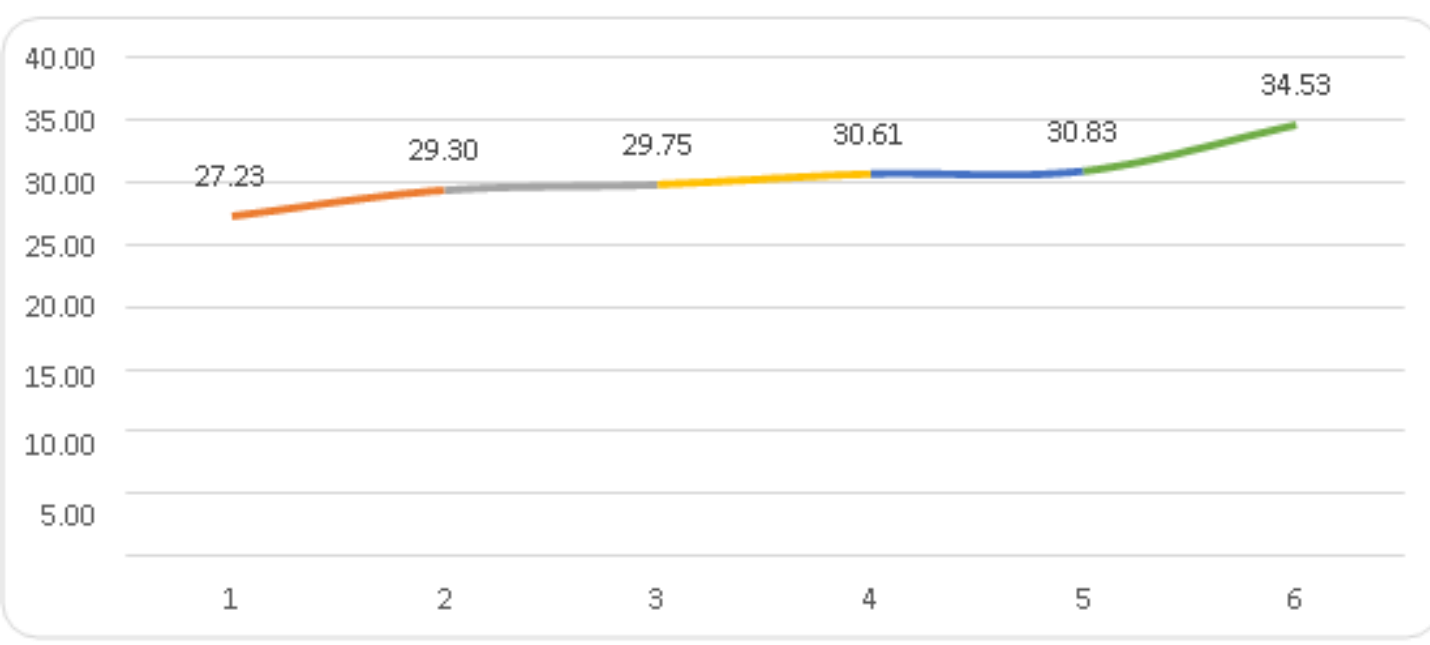

Figure 2. Observation Results of Shrinkage Cook

Cooking loss is the weight lost or the weight loss of meat samples due to cooking (Hafid et al, 2019). Cook losses on bali beef after measuring for 6 hours after cutting are under normal conditions between 30.64-43.28. According to Soeparno (2009) the percentage of cooking beef shrinkage is inthe normal range of $15-40 \%$. The lower the shrinkage of cooked meat the better the quality of the meat. It was further said that meat that had a low amount of cooking shrinkage had better quality because of the loss of nutrients during cooking would be less. The value of cooked beef shrinkage based on the research of Brahmantiyo (2000) ranged from 37.53 to $38.34 \%$, while the research of Yanti et al. (2008). That the value of cooked beef shrinkage ranges from 42.77 to $44.65 \%$. Based on the results of research conducted there are differences with the literature obtained as has been done byBrahmantyo (2000), because the beef used by Brahmantyo is a European cow while the cows used in this study are different bali cattle from cows Europe in general. 


\subsection{Meat Texture}

Table 2. Observation Results of Meat Texture

\begin{tabular}{ccccccccccc}
\hline \multirow{2}{*}{ Score } & \multicolumn{1}{c}{ Number of Panelist } & \multirow{2}{*}{ Frequency } & \multirow{2}{*}{ Percentage } \\
\cline { 2 - 8 } & $\mathbf{1}$ & $\mathbf{2}$ & $\mathbf{3}$ & $\mathbf{4}$ & $\mathbf{5}$ & $\mathbf{6}$ & $\mathbf{7}$ & $\mathbf{8}$ & & 0,00 \\
$\mathbf{1}$ & 0 & 0 & 0 & 0 & 0 & 0 & 0 & 0 & 0 & 35,42 \\
$\mathbf{2}$ & 4 & 3 & 3 & 3 & 7 & 5 & 6 & 3 & 34 & 42,71 \\
$\mathbf{3}$ & 5 & 7 & 6 & 4 & 5 & 6 & 3 & 5 & 41 & 21,88 \\
$\mathbf{4}$ & 3 & 2 & 3 & 3 & 0 & 1 & 3 & 4 & 21 & 0,00 \\
$\mathbf{5}$ & 0 & 0 & 0 & 0 & 0 & 0 & 0 & 0 & 0 & $\mathbf{1 0 0 \%}$ \\
\hline Total & $\mathbf{1 2}$ & $\mathbf{1 2}$ & $\mathbf{1 2}$ & $\mathbf{1 2}$ & $\mathbf{1 2}$ & $\mathbf{1 2}$ & $\mathbf{1 2}$ & $\mathbf{1 2}$ & $\mathbf{9 6}$ & \\
\hline
\end{tabular}

The physical quality of beef is influenced by many factors including the nation and gender of local cattle having different nationalities local beef is bright red, very little fat, with a rather smooth texture Tambunan (2001). After the panelist test conducted on Bali beef obtained the highest frequency of occurrence as much as $42.71 \%$ on a score of 3 which means the texture of meat is of medium value. The texture of meat produced from research Prasetyo (2013) the texture of meat produced in 3 markets in Malang has a smooth texture and produces soft meat. This is in accordance with research that has been done in the Kendari City RPH that uses a panelist test that produces the highest frequency of events at a score of 3 being $42.71 \%$ and the next highest score is a score of 2 which means smooth as much as $35.42 \%$.

\subsection{Firmness of Meat}

Table 3. Observation Results of Meat Firmness

\begin{tabular}{|c|c|c|c|c|c|c|c|c|c|c|}
\hline \multirow{2}{*}{ Score } & \multicolumn{8}{|c|}{ Number of Panelist } & \multirow{2}{*}{ Frequency } & \multirow{2}{*}{ Percentage } \\
\hline & 1 & 2 & 3 & 4 & 5 & 6 & 7 & 8 & & \\
\hline 1 & 0 & 0 & 0 & 0 & 0 & 0 & 0 & 0 & 0 & 0,00 \\
\hline 2 & 3 & 3 & 5 & 3 & 4 & 4 & 5 & 4 & 31 & 32,29 \\
\hline 3 & 8 & 8 & 7 & 6 & 7 & 8 & 4 & 8 & 56 & 58,33 \\
\hline 4 & 1 & 1 & 0 & 3 & 1 & 0 & 3 & 0 & 9 & 9,38 \\
\hline 5 & 0 & 0 & 0 & 0 & 0 & 0 & 0 & 0 & 0 & 0,00 \\
\hline Total & 12 & 12 & 12 & 12 & 12 & 12 & 12 & 12 & 96 & 100 \\
\hline
\end{tabular}

Antemortem and postmortem are two factors that affect meat tenderness. Antemortem factors such as genetics, including nation, species, and physiology, gender, age, management and stress. Changes in meat tenderness or texture when wilted are affected by changes in the holding capacity of the water. After the panelist test conducted on Bali beef the meat hardness data obtained obtained the highest frequency of occurrence at a score of 3 which means the value of mild softness was $58.33 \%$. Hardness of meat obtained from the slaughterhouse of Kendari City tends to have a rather rough texture. The results of this study are not much different from the observations of Anonymous (2015) who obtained the value of beef violence with an average of 2.5. Score 2 which means soft and score 3 which means rather soft, the results of observations indicate panelists prefer elasticity in beef samples. The ability of meat to maintain water content affects the level of hardness of meat. 


\subsection{Meat Moisture / Dryness of Meat}

Table 4. Observation Results of Meat Moisture / Meat Dryness

\begin{tabular}{ccccccccccc}
\hline \multirow{2}{*}{ Skor } & \multicolumn{1}{c}{ Number of Panelist } & \multirow{2}{*}{ Frequency } & \multirow{2}{*}{ Percentage } \\
\cline { 2 - 8 } & $\mathbf{1}$ & $\mathbf{2}$ & $\mathbf{3}$ & $\mathbf{4}$ & $\mathbf{5}$ & $\mathbf{6}$ & $\mathbf{7}$ & $\mathbf{8}$ & & 0,00 \\
1 & 0 & 0 & 0 & 0 & 0 & 0 & 0 & 0 & 0 & 30,21 \\
2 & 5 & 6 & 4 & 2 & 1 & 2 & 4 & 5 & 29 & 62,50 \\
3 & 6 & 6 & 8 & 8 & 10 & 9 & 7 & 6 & 60 & 7,29 \\
4 & 1 & 0 & 0 & 2 & 1 & 1 & 1 & 1 & 7 & 0,00 \\
5 & 0 & 0 & 0 & 0 & 0 & 0 & 0 & 0 & 0 & $\mathbf{1 0 0}$ \\
\hline Total & $\mathbf{1 2}$ & $\mathbf{1 2}$ & $\mathbf{1 2}$ & $\mathbf{1 2}$ & $\mathbf{1 2}$ & $\mathbf{1 2}$ & $\mathbf{1 2}$ & $\mathbf{1 2}$ & $\mathbf{9 6}$ & \\
\hline
\end{tabular}

Good meat quality in terms of meat color, appearance, odor, level of elasticity and moisture content or level of wetness of meat if held (Astawan, 2008; Hafid, 2011; 2018). After a panelist test on bali beef, the meat moisture / wetness data obtained with the highest frequency of occurrence occurred at a score of 3 which means medium, no liquid but the meat feels wet to the touch, fingers remain dry as much as $62.50 \%$. The results of research that have been done do not have much difference with the results of Anonymous (2015) observations of beef humidity value is 2.76 whilethe humidity of sample meat, with a score of 3 means rather dry.

\section{Conclusion}

Meat produced in Kendari City Slaughterhouse did not find meat that experienced changes in meat to DFD (Dark, Firm and Dry) or PSE (Pale, Soft and Exudative), meat in the normal pH range of5.55-5.73, Based on the AUS_MEAT color score, the color of meat in Kendari City Slaughterhouse ranges from a score of 4-5, the cooking losses of meat ranges from 30.64 to 43.28\%. ), the most meat thickness was score 3 or slightly soft $(58.33 \%)$ and the most meat moisture was score 3 or moderate $(62.50 \%)$.

\section{REFERENCES}

[1] Abidin. Z. 2008. Penggemukan Sapi Potong. Agro Media Pustaka. Jakarta.

[2] Alberle, E. D., J. C. Forrest, H. B. Hendrick, M. D. Judge and R. A. Markel. 2000. Principles of Meat science. W. H. Freeman and Co., San Fransisco.

[3] Alvarado, C. and S. McKee. 2007. Marination to Improve Functional Properties and Safety of Poultry Meat. J. Appl. Poult. Res. 16:113-120.

[4] Anonim .2015. Uji organoleptik daging sapi. http;//www.Keempukan/daging/sapi/bali.com. diakses Tgl 1 januari 2016.

[5] Amertaningtyas Dedes. 2013. Kualitas dging sapi segar dipasar tradisional dikecamatan poncokusumo kabupaten malang. Jurnal Ilmu dan Teknologi Hail Ternak. Vol 7 (1) $42-47$

[6] Antika D. D., S. R. Sukamto dan A. T. S. Estopangestie. 2005. Pengaruh Cara Pengemasan dan Suhu Penyimpanan Terhadap Awal pembusukan Daging Sapi. Jurnal Veterinaria medika 6(1): 15-20. 
[7] Arief, I.I., T. Suryati dan R. R. A. Maheswar, 2005. Sifat Fisik Daging Sapi Dark Firm Dry (DFD) Hasil Fermentasi Bakteri Asam Laktat Lactobacillus plantarum. Jurnal Media Peternakan 29(2): 76-82.

[8] Astawan, Made. 2008. Sehat dengan Hidangan Hewani. Jakarta: Penebar Swadaya.

[9] Awaluddin, 2006. Korelasi Antara Berat Femur Dengan Berat Edible Meat Kualitas III. J.Agrisains 7(3) : 177-182.

[10] Badan Pusat Statistik Sulawesi Tenggara, 2013. Laporan Hasil Sensus Pertanian 2013. Hal (22).

[11] Berg, R. T., B. B. Anderson and T. Liboriussen. 1978. Growth of Bovine tissue III. Genetic influenceson pattern of fat growth and distribution in young bulls. J. Anim Prod.

[12] Brahmantiyo, B. 2000. Sifat fisik dan kimia daging sapi Brahman Cross, Angus, dan Murray Grey. Media Veteriner. 7(2)9-11.

[13] Direktorat Kesehatan Masyarakat Veteriner. 2005. Buku pedoman Nomor Kontrol Veteriner Unit Usaha Pangan Asal Hewan.

[14] Hafid H. 2008. Strategi Pengembangan Peternakan Sapi Potong Di Sulawesi Tenggara Dalam Mendukung Pencapaian Swasembada Daging Nasional. Orasi Ilmiah Pengukuhan Guru Besar. Universitas Haluoleo, Kendari.

[15] Hafid H, R.E. Gurnadi, R. Priyanto and A. Saefuddin. 2010. Identifications of carcass characteristic for estimating the composition of beef carcass. J.Indonesian Trop.Anim.Agric. 35(1): 22-26.

[16] Hafid H. 2010. Regulasi Pemotongan Hewan Produktif untuk Mendukung Kelestarian Sumberdaya Ternak dalam Negeri. Prosiding seminar Nasional Peternakan PB-ISPI. Makassar. Hal 57-65.

[17] Hafid H. 2011. Pengantar Evaluasi Karkas. Cetakan Pertama. Unhalu Press, Kendari.

[18] Hafid, H. 2017. Pengantar Pengolahan Daging: Teori dan Praktik. Cetakan Pertama. Alfabeta, Bandung.

[19] Hafid H, Nuraini, D Agustina, Fitrianingsih, Inderawati, S H Ananda and F Nurhidayati. 2019. Characteristics of chicken nuggets with breadfruit substitution. Journal of Physics: Conf. Series 1360 (2019) Page 012020.

[20] Hardjosubroto, J. dan J.M. Astuti. 1993. Buku Pintar Peternakan. PT Gramedia Widiasarana Indonesia. Jakarta

[21] Kartasudjana, R. 2001. Proses Pemotongan Ternak di RPH. Direktorat Pendidikan Menengah Kejuruan. Jakarta

[22] Koswara. S. 2009. Teknologi Praktis Pengolahan daging. eBookPangan.Com

[23] Kuntoro B., Maheswari R. R. A., H. Nuraini (2013). Mutu fisik dan mikrobiologi daging sapi asal rumah potong hewan (RPH) Kota Pekanbaru. Jurnal Peternakan Vol 10 No 1: 1 - 8.

[24] Meat And Livestock Austalia, 2012. Australian Meat Food Service Professionals Proteins Australian Beef. Australia. 
[25] Mega, O. 2007. Sifat-sifat Organoleptik Nikumi Kuda dan Sapi pada Beberapa Frekuensi Pencucian (Leaching). J. Sain Peternakan Indonesia Vol. 2, No 1

[26] Prasetyo, H., C. M. Padaga, dan M. E. Sawitri. 2013. Kajian kualitas fisiko kimia daging sapi di pasar Kota Malang. J. Ilmu dan Teknologi Hasil Ternak 8(2): 1-8.

[27] Sastradipradja, D. 1990. Potensi Internal Sapi Bali Sebgai Salah Satu Sumber Plasma Nutfah Untuk Menunjang Pembangunan Peternakan sapi Potong dan Ternak Kerja Secara Nasional. Proc.Seminar Nasional Sapi Bali. Universitas Udayana. Denpasar.

[28] Soeparno. 2009. Ilmu dan Teknologi Daging. Gajah Mada University Press. Yogyakarta

[29] Standar Nasional Indonesia (SNI 3932, 2008). Mutu Karkas dan Daging Sapi. Badan Standardisasi Nasional (BSN), Jakarta.

[30] Standar Nasional Indonesia (SNI 01-3947-1995). Standar pemotongan Hewan. Badan Standardisasi Nasional (BSN), Jakarta.

[31] Sudjana. 2005. Metode Statistika. Trisito. Bandung.

[32] Suryadi, U. 2006. Pengaruh bobot potong terhadapkualitas dan hasil karkas sapi Brahman Cross.J. Pengembangan Peternakan Tropis. 31 (1):21 - 27.

[33] Suryana. A. 2000. Harapan dan Tantangan bagi Subsektor Peternakan dalam meningkatkanKetahanan Pangan Nasional. Pros. SeminarNasional Peternakan dan Veteriner. Bogor, 18-19 September 2000. Puslitbang Peternakan,Bogor. hlm. 21 - 28.

[34] Tambunan, F. (2001). Preferensi konsumen terhadap kualitas fisik daging sapi segar di pasar swalayan Hero Bogor dan pasar Padjajaran Bogor. Bogor: Institut Pertanian Bogor.

[35] Wello, B. 1986. Produksi Sapi Potong. Lembaga Penerbitan Universitas Hasanuddin Ujung Pandang, Makassar.

[36] Wulf, D. M., R. S. Emnett, J. M. Leheska, \& S. J. Moeller. 2002. Relationships among glycolytic potential, dark cutting (dark, firm, and dry) beef, and cooked beef palatability. J. Animal Sci. 80:1895-1903.

[37] Winarno F G. 2004. Kimia Pangan dan Gizi. PT Gramedia, Jakarta.

[38] Wirdahayati, R.B. dan A. Bamuallim. 1995. Parameterfenotipik dan genetik sifat produksi dan reproduksisapi Bali pada Proyek Pembibitan dan Pengembangansapi Bali (P3Bali) di Bali. Thesis Fakultas PascaSarjana, Institut Pertanian Bogor, Bogor.

[39] Yanti, H., Hidayati dan Elfawati. 2008. Kualitas daging sapi dengan kemasan plastic PE (polyethylen) dan plastic PP (Polypropylen) di pasar Arengka kota Pekanbaru. J. Peternakan. 5(1):22-27. 